\title{
TELLING (HER)STORY: AN OVERVIEW OF SUBALTERN STUDIES
}

ANTONIA NAVARRO TEJERO

Universidad de Córdoba

\section{THE RETHINKING OF HISTORY}

Claire Colebrook claims that post-structuralism was a form of ahistoricism and that new historicism marked something like a 'return' to history. After the supposed formalist relativism of the 1980s, literary criticism found history again, although now in a more rigorous and enlightened form. The fact that history has been rethought so thoroughly by new historicism is a consequence of certain moves made in post-structuralist thought. A broad range of concerns that motivated the post-structuralist endeavor prompted the rethinking of history and historiography. Problems of the narrative or inscriptive nature of all knowledge, of legitimization and situatedness, the contingency of disciplinary boundaries, a sense of political crisis, and the absence of consensus and shared narratives all led to a questioning of history as the repository of truth. Not only does new historicism itself draw upon the work of Lacan, Derrida, Foucault and the broad range of post-structuralist thought, but also the questions raised by the problem of historicism have intensified rather than been resolved. If it is the case that the writing of history is a form of power -and a specifically Western and modern form at that- then new historicism may best be seen as a quite specific response within a larger field of questions. ${ }^{1}$

There has been a long tradition of attempting to relate literary texts to history (a tradition dominated by the Marxist enterprise). Not only does the problem of relation presuppose that the categories of literature and history are somehow already apparent, but it also implies that there is an opposition between the two fields. While some writers are united in their attempt to think of history in terms other than that of a context or horizon in which texts would be related, there is often a sense that the literary or aesthetic will provide an 'other' to

1. Colebroor, Claire: New Literary Histories: New Historicism and Contemporary Criticism, Manchester and New York, Manchester University Press, 1997, p. 1. 
history. Literature is often seen as a privileged site where the determinism of history is disrupted, questioned or opened. New historicism has constantly demonstrated the malleability, contingency and contested character of the category of literature. By demonstrating the complex relationship between the production of the categories of both literature and history, new historicism has contested the boundaries of traditional historiography and literary criticism. New historicism has responded to the more general question of knowledge and power. ${ }^{2}$

\section{SUBALTERN STUDIES' HISTORY}

It is necessary to include in this study the thoughts of Subaltern Studies. Dipesh Chakrabarty, in "A Small History of Subaltern Studies», makes a summary of the history of Subaltern Studies as a discipline. A series of volumes dedicated to Subaltern Studies began in 1982 under the title of Subaltern Studies: Writings on Indian History and Society. Ranajit Guha -the founding editor, who is a historian of India and teaches at University of Sussex (UK)- and eight other scholars based in India, the United Kingdom and Australia constituted the editorial collective ${ }^{3}$. Not only do the series offer debates specific to the writing of modern Indian history but also Subaltern Studies exceeds the discipline of history, participating in contemporary critiques of history and nationalism, and of orientalism and euro-centrism in the construction of social-science knowledge. There have also been discussions of Subaltern Studies in many history and social science journals. Selections from the series have come out in English, Bengali, and Hindi and are in the process of being brought out in Tamil, Spanish, and Japanese. A Latin American Subaltern Studies Association was established in North America in $1993^{4}$.

Chakrabarty said that he concentrates on the discipline of history for two reasons:

"(a) the relationship between the new field of postcolonial writing and historiography has not yet received the attention it deserves, and (b) to answer critics who say that Subaltern Studies was once "good" Marxist history in the same way that the English tradition of "history from below» was, but that it lost its way when it came into contact with Said's Orientalism, Spivak's deconstructionism, or Bhabha's analysis of colonial discourse. $\nu^{5}$

2. Ibid., p. 2.

3. See their «Founding Statement» (1993).

4. As it exists now, the collective has the following members: Shahid Amin, David Arnold, Gautam Bhadra, Dipesh Chakrabarty; Partha Chatterjee, David Hardiman, Sudipta Kaviraj, Shail Mayaram, Gyan Pandey; M. S. S. Pandian, Gyan Prakash, Susie Tharu, and Ajay Skaria. Sumit Sarkar and Gayatri Spivak were members of the collective for specific periods in the 1980s and the 1990s respectively.

5. Chakrabarty, Dipesh: "A Small History of Subaltern Studies», in Henry Schwarz and Sangeeta Ray (eds.): A Companion to Postcolonial Studies, Oxford, Blackwell, 2000, p. 468. 
Moreover, in a wide-ranging critique of postcolonial thinkers, Arif Dirlik once suggested that the historiographic innovations of Subaltern Studies, while welcome, were more applications of methods pioneered by British Marxist historians, albeit modified by 'Third World sensibilities'.

Subaltern Studies raised questions about history writing that made the business of a radical departure from English Marxist historiographical traditions, inescapable. It started as a critique of two contending schools of history: the Cambridge School and that of the nationalist historians. Both of these approaches, declared Guha in a statement that inaugurated the series Subaltern Studies, were elitist, as those historians could not understand: «the contributions made by people on their own, that is, independent of the elite to the making and development of this nationalism ${ }^{6}$, even as they wrote up the history of nationalism as the story of an achievement by the elite classes, whether Indian or British.

The academic subject called 'modern Indian history' is a relatively recent development, a result of research and discussion in various universities in India, the United Kingdom, the United States, Australia, and elsewhere after the end of British imperial rule in August 1947. In its early phase, this area of scholarship bore all the signs of an ongoing struggle between tendencies, which were affiliated to imperialist biases in Indian history, and a nationalist desire on the part of historians in India to de-colonize the past. Marxism was understandably mobilized in aid of the nationalist project of intellectual de-colonization.

It looked for an anti-elitist approach to history-writing and in this it had much in common with the 'history from below' approaches pioneered in English historiography by Christopher Hill, E. P Thompson, E. J. Hobsbawm, and others. Both Subaltern Studies and the 'history from below' school were Marxist in inspiration, both owed a certain intellectual debt to the Italian communist Antonio Gramsci in trying to move away from deterministic, Stalinist readings of Marx. According to Chakrabarty, the word 'subaltern' itself and the concept of 'hegemony' so critical to the theoretical project of Subaltern Studies go back to the writings of Gramsci. Chakrabarty further states that as in the histories written by Thompson, Hobsbawm, Hill, and others, Subaltern Studies was also concerned about "rescuing from the condescension of posterity" the pasts of the socially subordinate groups in India, and hence the declared aim of Subaltern Studies was to produce historical analyses in which the subaltern groups were viewed as the subjects of their own history?

From its very beginning, Subaltern Studies positioned itself on an unorthodox territory of the left. What it inherited from Marxism was already in conversation with other and more recent currents of European thought, particularly those of structuralism. And there was a discernible sympathy with early Foucault in

6. GuHA, Ranajit: "On Some Aspects of the Historiography of Colonial India», in Ed. Ranajit Guha: Subaltern Studies I: Writings on South Asian History anti Society, Delhi, Oxford University Press, 1982, pp. 37-44.

7. ChaKrabarty, Dipesh: "A Small History of Subaltern Studies...», op. cit., p. 471. 
the way that Guha's writings posed the knowledge-power question. Guha retired from the editorial team of Subaltern Studies in 1988. In the same year, an anthology entitled Selected Subaltern Studies published from New York launched the global career of the project. Edward Said wrote a Foreword to the volume describing Guha's statement regarding the aims of Subaltern Studies as intellectually insurrectionary.

A text that can be considered as an insight into the subaltern is Foucault's I, Pierre Rivière (a peasant who killed his mother, sister and brother in 1835). It is interpreted as a protest against the intolerable conditions of everyday life in the French countryside, in which poverty, disease and exploitation deprived the peasants of their humanity, and their legally guaranteed claim to autonomous, rational subjecthood. In his making a bid to speak out, he is interpreted as a questioner of the system without the right to speak. In spite of the fact that feudalism had been legally abolished, the peasants were still perceived as monsters by other social groups.

The analysis of the discourses (over the meaning of the killings by the law) shows how the different elements available are selectively read or ignored in other to produce readings of the act and memoir as either monstrously evil or insane. Those laments, which are used to ground the legal case, are played down in the medical case and vice versa. In order to achieve a consistent argument, both are silent on the contents and argument of the memoir itself. It eludes that either classification or any serious consideration of it would undermine both the legal and medical cases. It is reduced to silence, taken as a manifestation of monstrosity or of madness. This silencing of the memoir renders it politically ineffectual. The only satisfactory way of silencing it, however, is by declaring Rivière insane, since to have him sane and monstrous would reflect on the common humanity of a society in which all were ostensibly equal. While Rivière is eventually committed, his suicide in prison is taken as a final statement that a reading of his deed and memoir in terms of insanity is inadequate.

The reading which the notes produce relies on a broad analysis of the historical context, the state of the peasantry and of the institutions of the law, medicine and politics, which stresses the unevenness in the social and economic shifts which mark the transition from feudalism to the bourgeois era. While it is but a version of this history, it is one with much explanatory power, showing the implications of the contest between discourses and interests over meaning for individual groups and classes and the effects of silencing on a class which had been led to believe that it now had a right to be heard.

Summing up, the Subaltern Studies discipline has two main objectives: (a) to challenge the elitism of Indian historiography in its nationalist and imperialist variants that saw the world of the peasantry and working class as simply exotic to the political and economic projects of the colonial period and irrelevant to the directions of Indian history; (b) to challenge this exoticisation via a historiography of the political (not pre-political) nature of popular struggles. Those two objectives were related through a critique of the terms of nationalist and imperialist historiographies and an attempt to use the documentation 
provided by the same historiography to understand better the precise modes of mobilization and the goals of popular struggles. The principal theoretical literature that influenced attempts at linking (a) and (b) above drew on Marx and Gramsci. Marx, not merely because of the Communist influences in West Bengal, where many of the original historians of the subaltern originated, but because his writings provided an indispensable vantage point.

Chakrabarty's definition of historicism is so wide and indiscriminate that it brings history itself into question. This, no doubt, is where his dabbling in Foucault and Heidegger has led him -after all, history itself is simply a record of different ways of 'being in the world' of capitalism, and all relations of power are rendered opaque by power itself. In his Provincializing Europe, Chakrabarty seems to be suggesting that the older Subaltern Studies' emphasis on struggles for social justice, however inchoate, were a bad dream from which a mature version has woken up. To defuse the charge that he has replaced struggle with a kind of existentialist conservatism, Chakrabarty strives mightily to argue that the real roots of oppression in modern Bengal (or India, or the Third World by extension) lie in a rampant Eurocentrism and historicism, not in income inequalities, mass poverty, patriarchy, the exploitation of labor, or the manifold oppressions of the state. The struggle is displaced on to the level of discourse.

This combination of nativism and orientalism marks a definitive impasse for Subaltern Studies. Chakrabarty asserts that Historicism is what allowed European domination of the world, thereby correcting one's naive assumption that it was the heavy artillery of imperialism. It does so by making modernity or capitalism look not simply global but global over time, by originating in one place and spreading to others. Historicism posits historical time as the measure of the cultural distance assumed to exist between the West and the non-West; in the colonies it legitimated the idea of civilization. It is in light of the above that we must assess Chakrabarty's claims about provincializing Europe, which he explains to be a way of exploring how European thought -both indispensable and inadequate to think about the thorny problems of colonial and postcolonial modernity- may be renewed from and for the margins.

In chapter three of his Provincializing Europe, Chakrabarty more or less tears up the idea that 'subaltern' refers to any particular social group or groups. We must assume that anyone who worlds the earth, experiences time, and so on, in ways that challenge the imperious code of historicism as subaltern. Social location itself is virtual; it is the tyranny of homogeneous, empty time that is the target of theoretical underlaboring. The practice of subaltern history is to take history, the code, to its limits in order to make its 'unworking' visible. ${ }^{8}$ Chakrabarty makes much of the fact that Indian historians are expected to know the works of their European counterparts, i.e. European history is part of the archive of Indian history, but that the reverse is not true. The point is

8. Chakrabarty, Dipesh: Provincializing Europe: Postcolonial Thought and Historical Difference, Princeton, N.J., Princeton University Press, 2000, p. 96. 
well taken but the issue is how effectively does he (or for that matter, Guha) use the European archive to write history. The Europe that he invokes is, by his own admission, hyperreal, and Europe's modernity is presented as some mythical Protestant ideal filtered through Locke and Hume. Huge chunks of counterhegemonic thought in Europe, and political economy, leave alone the critique of political economy, are simply ignored. What emerges is a caricature, one that is likely to be greeted with derision by European historians. Behind this, Chakrabarty maintains, lies an Indian tradition, unbroken before the colonial encounter, but which sustains itself now only in quotidian practice and in literature and art.

Guha starts with a tripartite division of historical development into three stages: slavery, feudalism, and capitalism, with historiographies that capture the peculiar aporias of each historical moment. In his Dominance without Hegemony, Guha's statement that "an uncoercive state is a liberal absurdity»" is perhaps a caution against getting carried away by a stark Europe-Other contrast but that insight is not developed in his comparative historiography. Eurocentric historians have tended to posit the rational rights-bearing individual, ostensibly a uniquely European phenomenon, as the heroic subject of their history.

According to Dirlik, postcolonial theory, the result of the arrival of the Third World intellectual in the First World academy as one of its more trenchant critics notes, has "rearranged the global situation, objectively quite pessimistic, into a celebration of the end of colonialism", and the necessary tasks for the near future as «the abolition of its ideological and cultural legacy» ${ }^{10}$. He continues saying that an exclusive focus on Eurocentrism as a cultural, ideological or discursive factor blurs the power relationship that dynamized it and endowed it with hegemonic persuasiveness. Postcolonial theory fails to explain why Eurocentrism, in contrast to local and regional ethnocentrisms, was able to define modern global history and «define itself as the universal aspiration and end of history ${ }^{11}$.

\section{THE SUBALTERN AS FEMALE}

Similarly, in "Can the Subaltern Speak?» -by the means of an extended discussion of sati-12 Spivak presents as emblem of the subaltern in the case of a political activist who sought to communicate her personal predicament through her suicide, but whose communication was foiled by the codes of

9. GuHA, Ranajit: Dominance without Hegemony: History and Power in Colonial India, Cambridge, MA, Harvard University Press, 1997, p. 23.

10. Dirlik, Arif: "The Postcolonial Aura: Third World Criticism in the Age of Global Capitalism», Critical Inquiry, 20 (Winter 1994), p. 343.

11. Ibid., p. 346-347.

12. The Hindu widow who immolates herself on the funeral pile with her husband's body. For a critique of this problematic, see Madhu Kishwar and Ruth Vanita (1987), Sujata Patel and Krishna Kuman (1988), Kumkum Sangari and Sudesh Vaid (1981), Lata Mani (1986), Ashis Nandy (1982 and 1988), Shakuntala Narasimhan (1991), Spivak (1987), and Rajeswari Sunder Rajan (1993). 
patriarchy and colonialism in which her actions were inevitably inscribed. Bhuvaneswari Bhaduri was a member of one of the many groups involved in the armed struggle for Indian independence. She hanged herself in 1926 at the onset of menstruation so that her death would not be diagnosed as the outcome of illegitimate passion. But her death was remembered as 'a case of illicit love'. Since her actions are not only inscribed, but also read in terms of the dominant codes of British imperialism and Indian patriarchy, Spivak concludes that the subaltern cannot speak. Her conclusion is preceded by a critique of Foucault and Deleuze, through which she discusses the dangers of re-inscribing imperial assumptions in colonial studies, and of Antonio Gramsci's and Ranajit Guha's treatments of subalternity, in which her main focus is Guha's analysis of the social structure of postcolonial societies.

In Spivak's provocative but complicated discussion of the subaltern as female, she seems to be arguing that the subaltern's voice/consciousness cannot be retrieved, and that analysis should indicate this impossibility by charting the positions from which the subaltern speaks, but 'cannot be heard or read'13. In a subsequent interview with Howard Winant, saying that she had been misunderstood, Spivak claimed that the purpose had been to counter the impulse to solve the problem of political subjectivity by romanticizing the subaltern. Instead of treating the subaltern as an unproblematic unified subject, she would apply to the subaltern "all the complications of 'subject production' which are applied to us.»" Spivak critiques Western poststructuralist theory as represented by Foucault and Deleuze and its tendency to reinstitute the notion of a Western sovereign subject in the act of deconstructing it. She goes on to posit the irretrievable heterogeneity of the subaltern subject, effaced by the orientalizing construction of sovereign subjectivity defined by power and desire. Foucault and Deleuze, she argues, inadvertently impose a Western Subject on the place of the subaltern. Spivak suggests that the term 'subaltern' refers to the margins (one can just as well say the silent, silenced center) of the circuit marked out by this epistemic violence [of imperialist/colonialist law and education], men and women among the illiterate peasantry, the tribals, the lowest strata of the urban subproletariat on the other side of the international division of labor form socialized capital.

In "Can the Subaltern Speak?» Spivak's aim is, in her words, "to learn to speak to (rather than listen to or speak for) the historically muted subject of the non-elite. $)^{15}$ Spivak suggests using the term 'subaltern' for everything that is different from organized resistance, justifying this usage by building on Guha's introduction to his Subaltern Studies where he is making an analysis of how a colonial society is structured, and what space can be spoken of as the subaltern space. Spivak's essay "Deconstructing Historiography» served

13. Spivak, Gayatri: «Can the Subaltern Speak?», in Cary Nelson and Larry Grossberg (eds.): Marxism and the Interpretation of Culture, Chicago, University of Illinois Press, 1988, p. 308.

14. SpIvAK, Gayatri: "Gayatri Spivak on the Politics of the Subaltern (An Interview with Howard Winant)», in Socialist Review, 3 (1990), p. 90.

15. SPIVAK, Gayatri: «Can the Subaltern Speak?»..., op. cit., p. 271. 
as the introduction to this selection. This essay of Spivak's and a review essay by Rosalind O'Hanlon published about the same time made two important criticisms of Subaltern Studies, which had a serious impact on the later intellectual trajectory of the project. Both Spivak and O'Hanlon pointed to the absence of gender questions in Subaltern Studies. They also made a more fundamental criticism of the theoretical orientation of the project. They pointed out, in effect, that Subaltern Studies historiography operated with an idea of the subject to make the subaltern the maker of his own destiny, which had not wrestled at all with critique of the very idea of the subject itself that had been mounted by poststructuralist thinkers.

Subaltern Studies scholars have since tried to take these criticisms on board. The charges about the absence of gender issues and the lack of engagement with feminist scholarship in Subaltern Studies have been met to some degree by some seminal essays by Ranajit Guha and Partha Chatterjee, and by contributions made by Susie Tharu on contemporary feminist theory in India. Partha Chatterjee's 1986 book Nationalist Thought and the Colonial World creatively applied Saidian and postcolonial perspectives to the study of non-Western nationalisms, using India as an example. Kamala Visweswaran distinguishes between the figure of 'woman' as subaltern and the question of subaltern women when considering the gendering of subalternity. She claims that there are two problems that mark the theorization of gender by the Subaltern Studies group: either gender is subsumed under the categories of caste and class or gender is seen to mark a social group apart from other subalterns ${ }^{16}$.

According to Said's reading of Michel Foucault, Orientalism characteristically implies that the dominant power successfully maximized itself at the expense of the subject peoples, who were rendered almost entirely passive and silent by conquest. Unsurprisingly, then, Said's text focuses almost exclusively on the discourse and agency of the colonizer. Spivak remedies this imbalance by a consistent attention throughout her career to the less privileged sectors of the colonized peoples and to their successors in the neocolonial era. To describe these social formations, she adapts the term 'subaltern' from Gramsci (to whom Orientalism is also heavily indebted conceptually), in whose writing it signifies subordinate or marginalized social groups in European (more specifically, Italian) society ${ }^{17}$.

Spivak's principal concern is the degree to which the (post)colonial subaltern, in particular, enjoys agency, an issue which she characteristically explores in terms of whether subalterns can speak for themselves, or whether they are condemned only to be known, represented, and spoken for in a distorted fashion by others, particularly by those who exploit them but also

16. VIsweswaran, Kamala: «Small Speeches, Subaltern Gender: Nationalist Ideology and Its Historiography", in Shahid Amin and Dipesh Chakrabarty (eds.): Subaltern Studies IX: Writings on South Asian History and Society, New Delhi, Oxford University Press, 1999, p. 90.

17. Gramsci himself invented the term 'subaltern' to replace 'proletariat' in order to evade prison censors. 
by 'concerned' outsiders like aid-workers or seemingly 'disinterested' scholars, such as anthropologists. The conclusion reached by "Can the Subaltern Speak?» is that there is no space from which subalterns can speak and thus make their interests and experience known to others on their own terms ${ }^{18}$.

In order to illustrate this argument, Spivak concentrates much of her attention on the mechanics of what she calls the 'itinerary of silencing,' which, paradoxically, accompanies the production of the (post)colonial subaltern as a seemingly freely speaking subject/agent in the discourses of the dominant order. Indeed, "Can the Subaltern Speak?» begins with an analysis of the silencing of the contemporary subaltern by western 'radical' intellectuals who ostensibly seek to champion those who are most oppressed by neocolonialism. Spivak's critique is partly methodological, partly political, in nature. First of all, she accuses figures like Deleuze and Foucault of assuming that they are transparent vis-à-vis the objects of their attention. In other words such 'radicals' too easily suppose that they are outside of the general system of exploitation of the 'Third World' in which western modes of cultural analysis and representation (including 'high' theory itself) and institutions of knowledge (such as the universities in which such theory is characteristically developed) are in fact deeply implicated. Secondly, while critics like Foucault and Deleuze announce the death of the (western, liberal, bourgeois, sovereign, male) subject of traditional humanism in the postmodern episteme, they retain what Spivak sees as a 'utopian' conception of the centered subject/agent in respect to marginalized groups, such as prisoners, women, or the Third World subaltern, who purportedly can speak for themselves despite all their various disadvantages. However, in ascribing a voice to the subaltern, according to Spivak, such intellectuals are in fact themselves representing (in the sense of speaking on behalf of or standing in for) the subaltern. This is not simply a problem in western radicalism. In "Subaltern Studies: Deconstructing Historiography» (1989), Spivak discerns a similarly 'utopian' vision of the resistant historical subaltern in the counterhegemonic work of the Subaltern historians of India with whom she and Said collaborated in the 1980s.

In methodological terms, "Three Women's Texts and a Critique of Imperialism" demonstrates one of the ways in which Spivak diverges most markedly from Said's The World, the Text, and the Critic (1983). The latter had provided a trenchant critique of Derrida (inspired by Foucault's account of his French colleague in Madness and Civilization) for allegedly failing to sufficiently articulate either critical or 'primary' cultural texts with 'worldly' (by which Said means real, political, historical) issues and engagements. By contrast, Spivak -who translated Derrida's Of Grammatology in 1976- attempts to demonstrate the usefulness of deconstruction to postcolonial studies at precisely this strategic level.

18. SpIVAK, Gayatri: «Can the Subaltern Speak?»..., op. cit., p. 103. 
Gail Hershatter states that one could generalize Spivak's observation and propose by saying that it makes more visible the workings of other markers of identity, such as race, ethnicity, religion, or nationality, and not just 'across the class spectrum,' but in their mutual interactions, illuminating, in turn, the process of class formation itself. This inclusive definition of subaltern is emphatically not meant to suggest that all oppressions (or resistances) are equal, and that everyone is a subaltern in the same way. According to Hershatter, her hope is not to render oppression uniform and thus somehow less onerous, but rather to trace the ways that oppressions can be stacked, doubled, intertwined ${ }^{19}$.

Fernando Coronil proposes that we view the subaltern neither as a sovereign- subject that actively occupies a bounded place nor as a vassal-subject that results from the dispersed effects of multiple external determinations, but as an agent of identity construction that participates, under determinate conditions within a field of power relations, in the organization of its multiple positionality and subjectivity. In his view, subalternity is a relational and a relative concept; there are times and places where subjects appear on the social stage as subaltern actors, just as there are times or places in which they play dominant roles. Moreover, at any given time or place, an actor may be subaltern in relation to another, yet dominant in relation to a third. Dominance and subalternity are not inherent, but relational characterizations. Subalternity defines not the being of a subject, but a subjected state of being. Yet because enduring subjection has the effect of fixing subjects into limiting positions, a relational conception of the subaltern requires a double vision that recognizes at one level a common ground among diverse forms of subjection and, at another, the intractable identity of subjects formed within uniquely constraining social worlds. While the first optic opens up a space for establishing links among subordinated subjects (including the analyst who takes a subaltern perspective), the second acknowledges the differentiating and ultimately unshareable effects of specific modalities of subjection. This relational and situational view of the subaltern may help anticolonial intellectuals avoid the we/they polarity underlying Spivak's analysis and listen to subaltern voices that speak from variously subordinated positions ${ }^{20}$.

\section{CONCLUSIONS}

To conclude, this whole study has been an attempt to trace the development of theories of historiography as exposed by Subaltern Studies mainly. I have analyzed how power and hierarchy permeate everything in the interface among Indians. I have included as well controversies about the subalterns' agency and the ways to empower silenced groups through the power of

19. Hershatter, Gail: «The Subaltern Talks Back: Reflections on Subaltern Theory and Chinese History", Positions, 1.1 (1993), p. 112.

20. CoroniL, Fernando: «Listening to the Subaltern: Postcolonial Studies and the Neocolonial Poetics of Subaltern States", in Laura Chrisman and Benita Parry (eds.): Postcolonial Theory and Criticism, Cambridge, The English Association, 2000, pp. 44-45. 
the word, de-empowering -thus- those who are dominant, and not the subalterns. There are no easy or permanent answers to the complexities of power structures. However, within the context of women's -and subalterns' in general- movements that threaten the social, religious and familial institutions and the environment instruments they promote, subaltern studies with a gender perspective seem to be demystifying the links between power structures, cultural practices and gender relations.

\section{SELECTED BIBLIOGRAPHY}

Chakrabarty, Dipesh: Provincializing Europe: Postcolonial Thought and Historical Difference, Princeton, N.J., Princeton University Press, 2000.

- "A Small History of Subaltern Studies», in Henry Schwarz and Sangeeta Ray (eds.): A Companion to Postcolonial Studies, Oxford, Blackwell, 2000, pp. 467-485.

Chatterjee, Partha: Nationalist Thought and the Colonial World, London, Zed, 1986.

- «Beyond the Nation? Or Within?», Economic and Political Weekly, 4.11 (January 1997), pp. 30-34.

Colebroor, Claire: New Literary Histories: New Historicism and Contemporary Criticism, Manchester and New York, Manchester University Press, 1997.

CoroniL, Fernando: «Listening to the Subaltern: Postcolonial Studies and the Neocolonial Poetics of Subaltern States.", in Laura Chrisman and Benita Parry (eds.): Postcolonial Theory and Criticism, Cambridge, The English Association, 2000, pp. 37-55.

Derrida, Jacques: Of Grammatology. Trans. Gayatri Chakravorty Spivak. Baltimore, John's Hopkins University Press, 1976.

Dirlik, Arif: "The Postcolonial Aura: Third World Criticism in the Age of Global Capitalism», Critical Inquiry 20 (Winter 1994), pp. 328-356.

Foucault, Michel: Madness and Civilization, New York, Pantheon, 1961.

- I, Pierre Rivière, Having Slaughtered My Mother, My Sister, and My Brother: A Case of Parricide in the Nineteenth Century. Trans. Frank Jellinek, Nebraska, University of Nebraska Press, 2002.

Gramsci, Antonio: Selections from the Prison Notebooks. Eds. and trans. Quintin Hoare and Geoffrey Nowell Smith, New York, International Publishers, 1973.

GuHA, Ranajit: "On Some Aspects of the Historiography of Colonial India», in Ranajit Guha (ed.): Subaltern Studies I: Writings on South Asian History anti Society, Delhi, Oxford University Press, 1982, pp. 37-44.

- and G. C. Spivak, (eds.): Foreword. Selected Subaltern Studies. By Edward Said, New York, Oxford University Press, 1988.

- ed. «Founding Statement.» Boundary, 2. 20. 3 (Fall 1993), pp. 110-121.

- Dominance without Hegemony: History and Power in Colonial India, Cambridge, MA, Harvard University Press, 1997.

Hershatter, Gail: "The Subaltern Talks Back: Reflections on Subaltern Theory and Chinese History», Positions, 1.1 (1993), pp. 103-130.

KIsHwar, Madhu and Vanita, Ruth: «The Burning of Roop Kanwar», Manushi, Sept.-Dec. 1987, pp. 15-29.

Mani, Lata: "Production of an Official Discourse on Sati in Early Nineteenth Century Bengal», Economic and Political Weekly, Review of Women Studies (26 April 1986), pp. 3240.

- «Contentious Traditions: The Debate on Sati in Colonial India», Cultural Critique, 7 (Fall 1986), pp. 119-156. 
Nandy, Ashis: «Sati: A Nineteenth Century Tale of Women, Violence and Protest», in Ashis Nandy (ed.): At the Edge of Psychology: Essays on Politics and Culture, New Delhi, Oxford University Press, 1980, pp. 1-31.

- "The Human Factor», The Illustrated Weekly of India, 17.23 (January 1988), pp. 20-23.

Narasimhan, Shakuntala: Sati: A Study of Widow Burning in India, New Delhi, Vinking, 1991.

O'Hanlon, Rosalind: "Recovering the Subject: Subaltern Studies and Histories of Resistance in Colonial South Asia», Modern Asian Studies, 22.1, (1988), pp. 189-224.

Patel, Sujata and Kuman, Krishna: "Defenders of Sati», Economic and Politial Weekly, 23 (January 1988), pp. 129-130.

SAID, Edward: Orientalism, New York, Random House, 1978.

- The World, the Text and the Critic, London, Faber, 1984.

- Culture and Imperialism, New York, Vintage, 1994.

SANGARI, Kumkum: "Sati in Modern India», Economic and Political Weekly, 1 (August 1981), pp.1284-1288.

SPIVAK, Gayatri: "Three Women's Texts and a Critique of Imperialism», in Henry Louis Gates (ed.): Race, Writing and Difference, Jr. Chicago, Chicago University Press, 1986, pp. 262-280.

- "The Rani of Sirmur: An Essay in Reading the Archives», History and Theory, 24. 3 (1987), pp. 247-272.

- "Can the Subaltern Speak?», in Cary Nelson and Larry Grossberg (eds.): Marxism and the Interpretation of Culture, Chicago, University of Illinois Press, 1988, pp. 271-313.

- "Subaltern Studies: Deconstructing Historiography», in Ranajit Guha and Gayatri Chakravorty Spivak (eds.): Selected Subaltern Studies, New York, Oxford University Press, 1989, pp. 3-32.

- "Gayatri Spivak on the Politics of the Subaltern (An Interview with Howard Winant)", Socialist Review, 3 (1990), pp. 81-97.

Sunder Rajan, Rajeswari: Real and Imagined Women: Gender, Culture and Postcolonialism, London, Routledge, 1993.

Visweswaran, Kamala: "Small Speeches, Subaltern Gender: Nationalist Ideology and Its Historiography», in Shahid Amin and Dipesh Chakrabarty (eds.): Subaltern Studies IX: Writings on South Asian History and Society, New Delhi, Oxford University Press, 1999, pp. 83-125. 